\title{
4. Sounds of History: Oratory and the fantasy of male power
}

\section{Marilyn Lake}

\section{In my wildest egotistical dreams}

In 1907, Arthur Atlee Hunt, the sensitive and self-regarding Secretary of External Affairs in the Prime Minister's Office, accompanied his 'Chief', Alfred Deakin, to the Colonial Conference in London. He reported on his experience, and that of the Prime Minister, in a series of confidential and detailed letters to his friend Bob Garran, in Melbourne, asking Garran to keep the letters as 'a memento of these important doings' ${ }^{1}$ Central to Hunt's reports to his friend were detailed accounts of Prime Minister Deakin's speech-making, widely praised as exemplary in its oratorical power.

What also becomes clear in Hunt's letters is the role of oratory as an indicator of masculine prowess in his Edwardian world. He was a keen analyst of the redeeming power of oratory and entertained fantasies on his own behalf. He wrote to Garran that he was sorely disappointed by Sir Wildred Laurier, Prime Minister of Canada, who was handicapped by 'a weak voice and a foreign accent'. He was surprised: 'Either he has faded from his former brilliancy, or else the standard of public speaking in the [Canadian] Dominion must be low, otherwise I cannot account for his reputation. ${ }^{2}$ He felt a nationalist pride in Deakin, who proved particularly impressive in the challenging role of after-dinner speaker. At the Pilgrims' Dinner, he was preceded by the Foreign Secretary, Sir Edward Grey, who 'in his curt, clear, incisive, cultured House of Commons manner was delightful to listen to, but there was no humour and no fire' . ${ }^{3}$ In Deakin's speech, on the other hand, there were both: ' $[\mathrm{H}]$ is sarcasm was polished and keen, and his enthusiasm was earnest and infectious.' Hunt judged it the best speech he had ever heard Deakin - or anyone else - ever make. ${ }^{4}$ He was pleased to report to Garran that the Prime Minister's renowned ability as a speaker meant that his 'position as the most prominent and forcible of all the Colonial Premiers is greatly strengthened: not only is he infinitely the best speaker but he seems to be the only one who has the courage to say exactly what he thinks'. ${ }^{5}$

Deakin surpassed all other Dominion leaders in oratorical skill; the other speakers at the 1907 conference, Hunt noted, talked 'platitudes of the commonest type'. 'I have often felt I should like to have their chance,' he confided to Garran, 'and though in my wildest egotistical dreams I could never hope to approach even our Chief's poorest efforts...yet I am confident that within five minutes' notice I could have made a better speech than any other Colonial representative. ${ }^{6}$ In 
the cultured world of public men, oratory conferred power and prestige, hence their preoccupation and its place in their dreams.

\section{Independent manhood}

Deakin's oratorical triumph in London in 1907 was especially important in the political context. Despite the achievement of Federation, Australia remained constitutionally subordinate to British power. The contradiction between Australia's continuing condition of colonial dependency and its assumed status as a self-governing nation exacerbated continuing tensions between Deakin and the Colonial Office and made the conference a tense and testy affair. Deakin's biographer, J. A. La Nauze, observed that Deakin approached the Colonial Conference as one would a 'battlefield', the proud colonial ever ready to defend Australia's honour in the face of imperial condescension. ${ }^{7}$

Deakin yearned for recognition of Australia's independent manhood, a condition exemplified by the nation he liked to call 'the great republic' ${ }^{8}$ In literature as in life, he was attracted to American strength, vigour and power. ${ }^{9}$ Harvard philosopher Josiah Royce enchanted him. After their momentous meeting in Australia in June 1888, Royce remembered Deakin in Scribner's as 'an admirer of America and of good scenery, a lover of life, of metaphysics, and of power' ${ }^{10}$ What we might call Deakin's republican desire, his love affair with American manhood, fuelled endless contests with the knighted Englishmen in the Colonial Office, who were loftily disposed, in their turn, to 'ignore Mr Deakin' and his litany of querulous complaints. ${ }^{11}$

A capacity for great oratory was one of the masculine virtues Deakin associated with the nation builders of 'the great republic'. He would have been pleased indeed to receive a letter from an American journalist comparing his speech-making at the Constitutional Conference in 1890 with the 'splendid oratory of Charles Sumner and Wendell Phillips'. Zadel Gustafson, who had heard him speak at the conference in Melbourne, in February that year, sent Deakin the article she had written, in which she compared his speech with the 'truth-charged burning words' of those great anti-slavery campaigners:

It is with the memories of these men's lives and truth-charged burning words, fresh in mind that I write to say how great the delight I felt in hearing the Constitution and institutions of my country set before this Conference of Australasia in the very hour of the conception of the nation that is to be. 12

Gustafson then analysed the elements that combined to render Deakin's speech into such powerful oratory. There were the cogent arguments that resulted from thoughtful study and investigation, his sympathy with his subject, the absolute fitness of the words chosen for his theme and the whole made luminous with 'the passion of Nationality'. As an American, Gustafson was especially moved 
by Deakin's admiration and knowledge of United States history, law and politics. 'If you can hold on your way with such lucidity, vigor, courage, discretion and passionate patience, as characterized your yesterday's speech, the union of these colonies will come,' she assured Deakin. And this historic event would occur largely through his efforts, which would also bring about closer relations with that 'great American Union of States' whose political character had been 'so clearly apprehended' by Deakin. ${ }^{13}$ The young Victorian politician would have rejoiced in this tribute, though he was probably less pleased by Gustafson's description of him to her readers as 'tall, straight and dark like a rugged impression of Philip II of Spain'. ${ }^{14}$ As an ardent Anglo-Saxonist, he would not liked to have been thought of as swarthy.

For Deakin, the Americans' oratory expressed their vigorous independent manhood and he would use his own oratorical power to redeem Australian manhood from its condition of colonial dependency, as he had done 20 years earlier in 1887, when he famously stood up to the British Prime Minister, the Marquis of Salisbury.

Prime Minister Deakin and Secretary Hunt had gone to the imperial capital in 1907, with the aim of challenging the 'limitations on our right of legislation' and 'removing from the Colonial Office practically all control of the self-governing Colonies' ${ }^{15}$ The British and Australian governments, he determined, must henceforth deal with each other as equals and as men. In his letters to Garran, Hunt complained that he was treated as a subordinate by his fellow officials in the Colonial Office. He wrote to Garran on 16 April:

You can hardly conceive what extremely unimportant persons we are in the minds of the Colonial Office. Not one of these exalted gentlemen have done me the honour to leave a card, certainly Sir Campbell Bannerman did so, but to expect Mr Johnson for example, to say nothing of Bertram Cox, Lucas and the rest to have to recognise my existence would be asking a great deal too much.

Hunt was affronted by his ignominious treatment: 'I may be permitted to wait in an ante-room and even carry in any papers that may be sent for, but beyond these ennobling duties I must not infringe the sanctity of the Conference by my profane presence. ${ }^{16}$ Hunt was effectively denied a voice at the conference, but there was little he could do except fret and fantasise. Deakin, on the other hand, was able to speak his mind and frequently did so.

\section{He spoke so well they thought he was beautiful}

For Deakin, oratory was a key weapon in the political battle in the imperial capital for recognition of the rights and equality of Australian manhood. He had learnt about the power of speech-making in the Empire in 1887, when, as a young man of thirty, he first journeyed to London as a member of the Victorian 
delegation to the first Colonial Conference, called to mark Queen Victoria's Golden Jubilee. There, with 'unrestrained vigour' and 'powerful retorts', he had, by his own account, trounced the British Prime Minister, Lord Salisbury. But he had been prepared for this performance many years before-in the Deakin family home, at Melbourne Grammar School, in the university debating club and in the Eclectics Society.

Nature favoured Deakin as a public performer: he was bright, charming, tall, dark and handsome, as Gustafson had noted, and a voracious reader with a capacious memory. He was also, no doubt because of these traits, favoured by male patrons: at school, by the headmaster, Dr Bromby, and a young master, J. H. Thompson, 'a handsome athlete whom [Deakin] was not alone in worshipping', in the words of biographer La Nauze; at university, by Charles Pearson, erstwhile Professor of Modern History at King's College, London, who convened the Debating Club; in journalism, by David Syme, the influential proprietor of the Age, who gave him work and supported him as a twenty-two-year-old candidate for election to the Victorian Parliament, and by James Service, Victorian Premier, his patron in Parliament. ${ }^{17}$ His biographer also found him attractive. 'His physical endowments,' La Nauze wrote with manly appraisal, 'lay in his appearance, his bearing and his voice.' Deakin's eyes 'gave vivacity to his handsome features. His voice, a light baritone in quality, had a rich timbre and a wide range. His quick gestures were adapted unconsciously to express rhetorical emphasis as he gained experience in speaking. ${ }^{18}$

As a young man, Deakin was an orator in the making. His 'Notebooks' from the 1880s report his interest in studying technique and effect. From English constitutionalist Walter Bagehot, he noted the importance of constructing an argument: 'Of all the pursuits ever invented by man for separating the faculty of argument from the capacity of belief, the art of debating is probably the most effectual.' From American writer Walt Whitman, he learnt the charismatic effect of the 'right voice':

Surely whoever speaks to me in the right voice

Him or her I shall follow

As the water follows the moon silently with

Fluid steps, anywhere around the globe. ${ }^{19}$

Deakin had travelled part-way round the globe in 1885, on a voyage that took him across the Pacific Ocean to California to investigate irrigation, and then on to the east coast to New York and Boston, a trip whose main objective was a pilgrimage to the grave of Whitman's mentor, Ralph Waldo Emerson.

Two years later, in London, in 1887, Deakin had the opportunity for the first time to speak as a statesman on the world stage and he found exactly the 'right voice'. He wooed British statesmen and leaders of society with an 'oratorical 
power' that the Liberal politician Sir Charles Dilke found 'remarkable'. Dilke quickly came to the view that Deakin was 'the man of greatest promise in all Australia... a great administrator, a man of extraordinary charm and eloquence' ${ }^{20}$ Dilke, like many of his countrymen, seemed to find Deakin's eloquence especially surprising in 'a native born Australian', as the Parliamentary Under-Secretary, Sir William Hillier Onslow, who shared Holland's duties as president of the 1887 conference, referred to him. ${ }^{21}$

Shortly after Deakin's arrival, Onslow, a former governor of New Zealand, sent him an invitation to join him for dinner at Richmond Terrace, Whitehall: 'I was delighted to hear of your safe arrival. Lady Onslow is still abroad but returns this week. If you are disengaged will you give us the pleasure of your company at dinner here on Thursday $22^{\text {nd }}$ at $8.15 ?^{\prime 22}$ By the time Deakin left England that year, Onslow, like so many others, had concluded that Deakin was no ordinary colonial. While other British subjects delivered themselves of platitudes and pledges of loyalty to the Mother Country, Deakin struck an entirely different note. In Deakin, they had 'a real live man'. ${ }^{23}$

At a dinner hosted by the Imperial Federation League, Deakin was provided with his first opportunity to speak on political matters in London, when his colleague Sir James Lorimer was unable to attend. 'I ought to have been better prepared \& to have done better,' he wrote home, 'but it was not altogether a failure. Some thought it the speech of the evening. ${ }^{24}$ The Age report - from its anonymous correspondent (was it Deakin himself?) — echoed this judgment: '[I]n the unanimous opinion of all present [it was] the speech of the evening.' His theme was the imperative of Australian independence: the colonies 'were too proud to remain in such a dependent condition when they had been so amply endowed with the privileges of self-government'. The Duke of Cambridge responded with 'a warm eulogium on the ability of Mr Deakin's speech' ${ }^{25}$

Deakin spoke so well they thought he was beautiful. English public men adored him and showered him with invitations to their city clubs and country houses. Initially, he had used letters of introduction from Charles Pearson (to Dilke and M. E. Grant Duff, for example), but as word spread about this charming and challenging young man from the Antipodes, so the requests for his company and literary contributions to the London magazines poured in. The editor of the Fortnightly Review 'seemed to take greatly to me \& strongly presses me to write him a colonial article...Murray's Magazine has pressed the same thing but I declined all' 26

One of the many leading public men to whom he was introduced in London was Sir George Trevelyan, historian and politician and biographer of Macaulay. They met at a lunch hosted by Lady Holland, Trevelyan's sister, Macaulay's niece and the wife of Sir Henry Holland, the Colonial Secretary. At lunch, Deakin was seated next to Trevelyan: 'very cultured, clever \& chatty,' he noted dismissively 
in his letter home. Though Deakin judged Trevelyan to be 'a light weight all round', he nevertheless noted down Trevelyan's remark that 'this was the age in which one fine art, that of speaking, has been brought to perfection' ${ }^{27}$ Deakin knew that it was an art in which he excelled.

His eloquence particularly impressed the Colonial Secretary. 'Sir H. Holland was pleased,' Deakin wrote to his sister, '\& Service says he has fallen in love with me as other elders have done. I cannot see this. ${ }^{28}$ But he came round to this view, a few days later, when after conference discussions on the subject of defence, the Lords of the Admiralty, Sir A. Hood and Sir A. Hoskins, 'came right up to me \& poured in broadsides because of my independent views of Victoria'. But then, 'Sir H. Holland came to the rescue - \& Service declares his personal attentions are most marked to me-In a pleasant interview I had with him he expressed his regret at my declining the KCMG \& wished me to take it. I think I have made a friend in him. ${ }^{29}$

Holland was considered a proficient speaker, but not an orator, an important distinction: '[I]n style and tone he is the model of a permanent official; and, though not an orator, is quite capable of making a clear and business like statement on any point of procedure or policy. ${ }^{30}$ Deakin's assessments of men usually looked to their speaking capacity, which he interpreted as a reliable indicator of their manhood more generally. William Gladstone was 'strong in passion \& strong in natural gifts of an oratorical order, strong in a kind of culture which fed \& elevated his oratory'. ${ }^{31}$ Poor speakers were explained as effeminate or feeble. Arthur Balfour, the young Secretary for Ireland, was 'foppish unprepossessing in appearance, egotistical and without oratorical grace'. On a visit to the House of Commons, Deakin 'heard no speaking of special order. Two feeble old Liberals moved an amendment \& an aldermanish but capable conservative made a good and solid reply. ${ }^{32}$

Just as a capacity for oratory was a marker of powerful manhood, so it rendered women 'masculine', as Deakin described Annie Besant, whom he heard speak in Edinburgh over Easter. His critical analysis of her performance judged it according to a number of masculinist criteria. She had an

intense voice good \& ringing not soft or winning - never smiles \& her humour what there is of it grim \& not pleasant-her accent quite educated \& cultured. Her language clean \& well chosen, admirably simple $\&$ strong. I should say her lecture was familiar to her, tho she glanced now \& then at her notes. Her sentences were well formed \& finished, not so flowing nor so theatrical nor so dominating as Mrs Britten, but concise \& more sinewy in some respects the best speaker among women I have heard. But just as her audience was old, so was the treatment of her speech. 
Deakin thought her arguments 'clean in expression \& utterance, but by no means original in any single thought, utterly barren of constructive ideas' ${ }^{33}$ To the extent that she was a good speaker — indeed, the best speaker among women he had heard - she sacrificed her femininity. Oratory was a masculine performance; womanliness demanded a soft voice and winning smiles.

\section{The British Prime Minister trounced}

It was in the closed session of the 1887 conference, after Holland's business-like opening address, that Deakin engaged in his legendary confrontation with the Prime Minister, Lord Salisbury, who was recognised as 'a great master of expression' and hence a worthy opponent. The issue was the future of the New Hebrides. Salisbury told the colonials that they had no business interfering with imperial policy in the Pacific Ocean and that France had made a good offer in promising to cease sending convicts to New Caledonia, in return for recognition of its sovereignty over the islands. The colonial premiers responded with due deference and 'whispering humbleness', but Deakin would have none of it. Of his speech that day, the Age reported: 'The remarks of the junior delegate from Victoria were brightly delivered and bolder in tone than those of the preceding speakers, and enabled him for the second time since his arrival to carry off the palm of oratory from all his compeers.' ${ }^{34}$ In a letter to his family, Deakin wrote:

Then [the turn for the colonial representatives came] \& one vied with another in congratulations felicitations \& glorifications - I took quite a different key \& gave them the Victorian view with some energy- It satisfied my friends \& won me some praise \& some declared it the speech of the day-I might and ought to have done much better. ${ }^{35}$

This encounter between Lord Salisbury and the junior delegate from Victoria would become central to Deakin's later account of the 'federal story', a founding moment in his history of Federation, an account in which he would transform an experience of imperial domination into a fantasy of powerful masculine triumph. Of the British Prime Minister, he wrote: 'His tone breathed the aristocratic condescension of a Minister addressing a deputation of visitors from the antipodes whom it became his duty to instruct in current foreign politics for their own sakes.' His Australian colleagues, he wrote, responded 'with bated breath and whispering humbleness, apologising for the strong feeling which had been expressed in the colonies'. ${ }^{36}$ Then Deakin rose to his feet and, according to his own third-person account: 'He broke quite new ground not only with unrestrained vigour and enthusiasm on the general question as his colleagues had before him, but because he did so in a more spirited manner, challenging Lord Salisbury's arguments one by one and mercilessly analysing the inconsistencies of his speech. ${ }^{37}$

Rising to revolutionary rhetoric, Deakin 
went on to declare in an impassioned manner that the people of Victoria would never consent to any cession of the islands on any terms and that the Australian born who had made this question their own would forever resent the humiliation of a surrender which would immensely weaken their confidence in an Empire to which hitherto they had been proud to belong. ${ }^{38}$

The effect of such a bold statement, he reported, was 'electrical'. 'Lord Salisbury several times stared at the speaker, as well he might...[in] considerable amazement at his plain speaking and in some discomfort at the stern debating retorts to his inharmonious contentions. ${ }^{39}$ The British Ambassador in Paris was promptly informed that nothing was to be ceded to the French. Deakin was undoubtedly pleased with his performance, but the lesson he drew from his experience at the Colonial Conference was that had the colonies spoken in unison, with one voice, their achievements would have been all the greater. In union lay power. Small wonder that the next year Royce concluded that Deakin liked power and that separation from Britain was inevitable. ${ }^{40}$

\section{In conclusion: only talk}

Deakin's experience of colonial subjection was, by his own account, demeaning and humiliating, yet he managed to transform it, in memory, into a story of potent triumph. Yet his victory over the British Prime Minister, like Atlee Hunt's impressive speech-making, was largely a consoling fantasy. Even with the achievement of federal union, Australia remained in a condition of colonial dependency, subject to British power, still complaining about French (and German and Japanese) intentions in the Pacific for years to come.

Hence the anxiety that accompanied Deakin's attendance at the conference in 1907. Hunt noted that Deakin was plagued by over-worry and indigestion. ${ }^{41}$ Deakin referred to the conference in 1907 as an imperial conference, a gathering he fantasised as a meeting between equal autonomous governments, the same meaning he would give to 'Imperial Federation'. He arrived in London determined to remove all power from the Colonial Office, but had to make do with a promise to establish a new Dominions Office, headed by veteran Colonial Office man Sir Charles Lucas (one of the officials who had ignored Secretary Hunt). ${ }^{42}$ Deakin's capacity for oratory, in his view, redeemed Australian manhood, but in the event it also served to consolidate his country's dependency.

While Deakin raged inwardly at Australia's humiliation - at being denied the right to contribute to defence and foreign policy, at Australia being treated as an object of negotiation between the great powers - he took consolation in his oratorical powers. Deakin had mastered the art of oratory and oratory had mastered him. Oratory offered Deakin (and in his dreams, Secretary Hunt) the taste of masculine power. But Deakin also knew the limits of 'talk'. In his first 
letter home from England on 31 March 1887, he announced: 'I have made my debut in London society \& am prepared to give judgment upon it at once.' He had attended an 'At Home' of Countess Stanhope.

She was very glad to see me she said, tho' I doubt if she knew where I came from \& probably said the same thing to a couple of hundred others. Somebody else was announced right on my heels \& so I passed... The dinners are just as our dinners, people dress better \& more people talk well. Some brilliantly, but it is only talk \& therefore worth nothing. ${ }^{43}$

Oratory was an art and a gift, and it lifted some men above others, but it was, after all, just talk.

In oratory, Deakin sought to redeem Australian manhood, and his own speech-making undoubtedly played a significant role in the achievement of Federation, yet his country remained in a position of colonial dependency, subservient in important matters to the Colonial Office. The strain generated by the tension between that dependency and his republican desire for manly independence took its psychic toll. Biographer La Nauze noted that after the 1907 conference, something was damaged in Deakin and could not be repaired. W. M. Hughes, looking at Deakin across the benches of the House of Representatives on his return, concluded that Deakin had had a nervous breakdown. 44

\section{ENDNOTES}

1 Arthur Atlee Hunt to Bob Garran, 16 April 1907, Hunt papers 52/767, National Library of Australia.

2 Hunt to Garran, 25 April 1907, Hunt papers 52/772A.

3 Ibid.

4 Ibid.

5 Ibid.

6 Hunt to Garran, 25 April 1907, Hunt papers 52/772B.

7 La Nauze, J. A. 1965, Alfred Deakin A Biography, Vol. 2, Melbourne University Press, Melbourne, p. 500 .

8 Lake, Marilyn 2007, “"The Brightness of Eyes and Quiet Assurance Which Seem to Say American”: Alfred Deakin's Identification with Republican Manhood', Australian Historical Studies, Vol. 38, No. 129, pp. 32-51.

9 Ibid.

10 Scribner's Magazine, IX, No. 1 (January 1891), p. 78.

11 Sir Francis Hopwood, note, 4 April 1908, CO418/60/105.

12 Zadel Gustafson to Alfred Deakin, 6 March 1890, Deakin papers 1540/11/4, National Library of Australia.

13 Ibid.

14 Ibid.

15 Hunt to Garran, 18 April 1907, 52/769.

16 Hunt to Garran, 16 April 1907, 52/767C.

17 La Nauze, Alfred Deakin, Vol. 1, p. 18.

18 Ibid., p. 24.

19 Notebooks, Deakin papers 1540/3/11. 
20 La Nauze, Alfred Deakin, Vol. 1, p. 91.

21 Ibid., p. 94.

22 Onslow to Deakin, no date, Deakin papers 1540/9/344.

23 La Nauze, Alfred Deakin, Vol. 1, p. 94.

24 Deakin travel diary, Deakin papers 1540/2/39/.

25 News clipping, undated report by special correspondent (Deakin himself perhaps?), Deakin papers 1540/9/478.

26 Travel diary, Deakin papers 1540/2/39/.

27 Ibid.

28 Ibid.

29 Ibid.

30 Age, 14 May 1887.

31 Travel diary, Deakin papers 1540/2/39.

32 Ibid.

33 Ibid.

34 Age, 14 May 1887, Deakin papers 1540/9/474.

35 Deakin's travel diary, 1887, 2/2/39.

36 Deakin, Alfred 1963, The Federal Story, edited and introduced by J. A. La Nauze, Melbourne University Press, Melbourne, p. 21.

37 Ibid., p. 22.

38 Ibid., p. 23.

39 Ibid., p. 23; La Nauze makes the point that there were other slightly different, less heroic, versions of the encounter than Deakin's, but what interests me is precisely Deakin's version of it. See La Nauze, Deakin, Vol. 1, pp. 96-7.

40 Royce, Josiah 'Reflections after a Wandering Life in Australasia', Atlantic Monthly, Vol. LXIII, p. 827.

41 Hunt to Garran, 16 April 1907, 52/767.

42 Ibid.

43 Deakin's travel diary, 1887, 2/2/39.

44 LaNauze Deakin Vol. 2, p. 514; Hughes to Jebb quoted in LF Fitzhardinge, 1964, William Morris Hughes A Political Biography vol. 1, Angus and Robertson, Sydney, p. 191. 